\title{
DETERMINANTS OF PRACTISING SELECTED FORMS OF PHYSICAL ACTIVITY IN A GROUP OF ADMINISTRATIVE AND OFFICE WORKERS
}

\author{
ANNA KOWALCZYK1, EWELINA KOZŁOWSKA² \\ Medical University of Lublin, Faculty of Health Sciences ${ }^{1}$, Laboratory of Epidemiology ${ }^{2}$ \\ Mailing address: Ewelina Kozłowska, Medical University of Lublin, Laboratory of Epidemiology, 4/6 Staszica Street, \\ 20-081 Lublin, tel.: +48 81 4486942, fax: +49 81 4485151, e-mail: ewelina.kozlowska@umlub.pl
}

\begin{abstract}
Introduction. In recent years, a decline in the level of physical activity has been observed all over the world. The number of professions where work is performed in a sitting position has increased. This has had many consequences for our health, the society, and the economy. The aim of this work was to determine which forms of physical activity are the most popular in administrative and office workers, depending on the motives which encourage them to be active. Material and methods. In 2014, a diagnostic survey was carried out among 937 persons in administrative and office positions using a questionnaire form designed by the authors. The study involved persons aged 18 to 65 years, and most of the respondents were female $(\mathrm{n}=669)$. A qualitative analysis of the data was carried out using logistic regression, and the findings were considered statistically significant at $\mathrm{p}<0.05$. Results. Changing the shape of one's body was found to be the main determinant of using the gym among the respondents. Persons who jogged regularly, on the other hand, did so in order to increase physical fitness, and those who practised Nordic walking were motivated by the need to care for their health. As far as swimming is concerned, persons who had friends that engaged in this form of activity undertook it almost ten times more often than those who did not have such support from their family and friends $(\mathrm{OR}=9.58)$. Respondents who desired to meet new people were over five times more likely to choose team games as an active form of spending their leisure time $(\mathrm{OR}=5.21)$ than other respondents. Finally, those who engaged in physical activity in order to strengthen family bonds preferred playing and playing games with children in the open air. Conclusions. The predominant forms of physical activity which were regularly performed by the respondents were walking, cycling, and doing gymnastic exercise at home. The respondents were mainly motivated to pursue these activities due to their desire to relieve tension and stress, care for their health, and lose weight or maintain a healthy weight.
\end{abstract}

Key words: physical activity, determinants, administrative and office workers

\section{Introduction}

Physical activity is one of the basic determinants of good health. Unfortunately, changes in the lifestyle of the citizens of highly developed countries are making it increasingly difficult to perform a sufficient amount of daily physical activity. This tendency directly stems from technological development. In the professional world, manufacturing work which was once performed manually is now done using machines. In consequence, it is not only administrative and office workers who are exposed to sedentary styles of work, although this occupational group constitutes a classic example of persons with a high-risk of hypokinesia. Performing most of the work in a sitting position induces people to avoid active forms of rest and leisure or even being active when travelling between their home and work. Such negative habits tend to be transferred to the family life, and they contribute to reducing the general level of physical activity, as is the case in the Polish society. This is one of the reasons why we are currently struggling with an epidemic of excess weight and obesity, cardiovascular diseases, musculoskeletal pain, and other diseases caused by a sedentary lifestyle [1-3]. In order to counteract this adverse trend, it is necessary to determine what motivates those particularly exposed to a lack of physical activity to undertake it.

Resting and having leisure time when no compulsory tasks are carried out are essential for the human body to function normally. Depending on the work which is done and everyday lifestyle, it is recommended that a person rest in either a predominantly active or predominantly passive form. For persons performing mental work, spending most of the day in a sitting position, active rest is recommended. Physical activity done in one's free time develops creativity and supports memory function, which in turn translates into an improvement in a person's health condition and general well-being [4]. Benefits for health and well-being can be experienced already after engaging in physical activity a few times, and the extent to which recommendations regarding health-enhancing physical activity are complied with will significantly affect the length and quality of Polish people's lives. This is particularly important in the context of contemporary challenges for Poland and Europe related to the rapid increase in the percentage of older people in the total number of persons working professionally [5].

The Eurobarometer survey shows that Poles are mainly motivated to engage in physical activity by the willingness to improve their health (59\%) and desire to increase their physical fitness (35\%) [6]. The analyses we have conducted so far which examined the determinants of physical activity among persons professionally exposed to spending long hours in a sitting position have made it possible to distinguish the following motives for spending leisure time in an active way: the need to lose weight or maintain a healthy body weight $(45 \%$ of all respondents surveyed), the need to care for one's health (44\%), and the 
desire to relieve tension and stress (43\%). The most common forms of physical activity were found to be walking (undertaken by $61 \%$ of all respondents) and cycling (52\%). The results of our research, including those regarding sociodemographic variables, have been presented in detail in our previous publications $[7,8]$. The current article presents an in-depth analysis of the data we have collected which includes both the gender and age of the respondents.

The aim of the current article is to establish the determinants of undertaking particular forms of physical activity in a group of administrative and office workers.

\section{Material and methods}

The material for qualitative analysis was collected in a diagnostic survey between March and May 2014. For this purpose, an original questionnaire form was designed. It included questions about the forms of physical activity regularly undertaken by the respondents, the motivation for undertaking them, and socialdemographic variables. Diagnostic surveys carried out using questionnaires are the most popular method applied in studies of the physical activity of selected groups of people. They do not interfere with the internal state of the respondents, are relatively inexpensive, and make it possible to conduct research in a natural setting, which was the respondents' workplace in this case. Over the years, several questionnaire tools investigating the level of physical activity of different populations (children, adults, older people, athletes, etc.) have been developed. They were drawn up mainly in order to determine the frequency, volume, and intensity of the physical effort undertaken or the influence of the level of physical activity on the risk factors of different diseases [9]. However, the starting point for our study was to determine factors affecting physical activity, and therefore an original questionnaire form was specially designed for the purpose of this work.

Due to the nature of the study and availability of the respondents, intentional selection of the population sample was performed based on the following criteria: employment in an administrative and office position in an institution located in the Lublin Province and age ranging from 18 to 65 years. A total of 937 persons participated in the survey. They worked at 21 city offices, 15 district offices, 54 commune offices, 7 higher education institutions, as well as at branches of the Social Security
Office, Agricultural Social Insurance Fund, and Statistical Office and 11 other institutions in the Lublin Province. As far as the gender of the respondents is concerned, women prevailed over men (669 vs. 268), which reflected the predominance of women in administrative and office professions in Poland. The age of the respondents ranged from 22 to 64 years, and their average age was 40.96 years $(\mathrm{SD}=10.57)$. The population examined was divided into three age cohorts which had a similar number of respondents: a group which included young persons aged 22-34 years $(n=327)$, a group composed of persons aged $35-45$ years ( $n$ $=291$ ), and a group consisting of middle-aged and older persons aged $46-64$ years $(n=319)$.

The collected material was subjected to statistical analysis, which was performed using Statistica 10 software. The popularity of particular forms of physical activity, taking into account the gender and age of the respondents, was analysed using Pearson's chi-square nonparametric test. Statistical significance was set at $\mathrm{p}<0.05[10]$. An assessment of the impact of factors which motivated the respondents to undertake physical activity (explanatory variables) on the selection of particular forms of motor activities was carried out using logistic regression. Inferences were made at the level of $\mathrm{p}<0.05$, and insignificant variables were removed from the model. The results were presented in the form of the odds ratio and 95\% confidence interval.

Logistic regression is one of the most commonly used forms of regression analysis. It can be applied when the dependent (explained) variable is dichotomous (has two values) [11]. This is the case when the presence or absence of a phenomenon is determined, which is the regular practice of selected forms of physical activity is the current study. Using logistic regression made it possible to estimate the probability that a given form of physical activity will be chosen depending on a particular type of motivation for undertaking physical activity. Statistical analyses in the works of other authors are limited only to determining the presence or absence of relationships between similar variables, and they do not make it possible to determine the levels of probability [12-14]. The authors of this work have made an attempt to fill this gap.

\section{Results}

The respondents' preferences as to selecting particular forms of physical activity were found to be dependent on the

-22-34 years $\square$ 35-45 years $\square$ 46-64 years

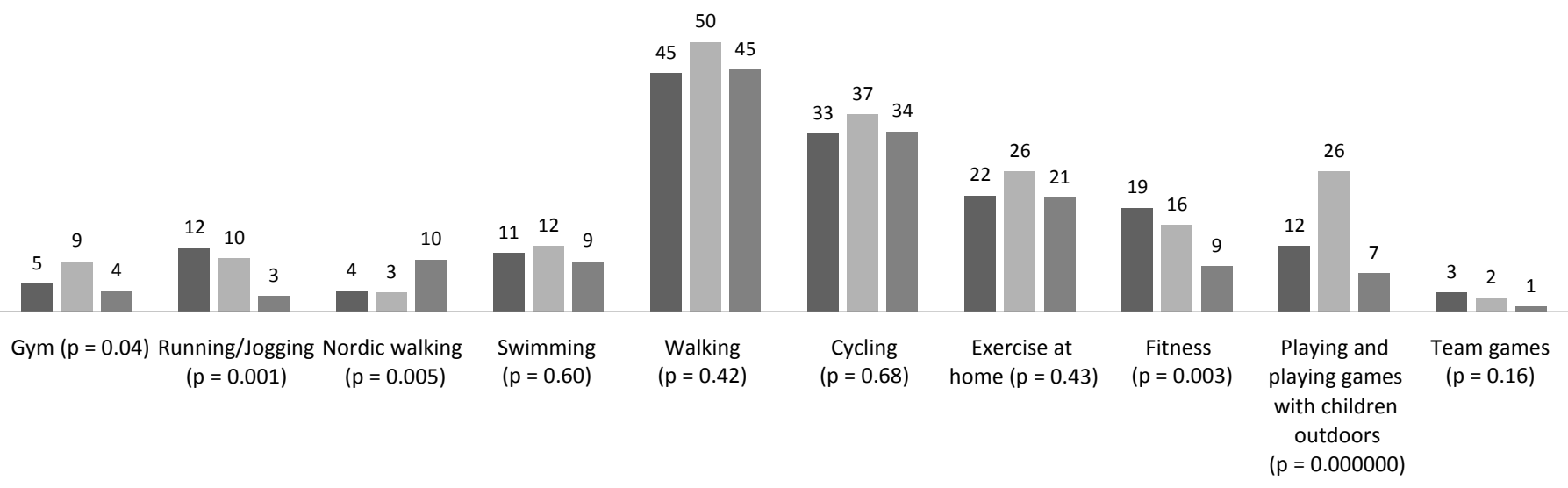

Figure 1. Popularity of selected forms of physical activity among female respondents in particular age groups [\%] 
- 22-34 years $\quad$ 35-45 years $\quad$ 46-64 years

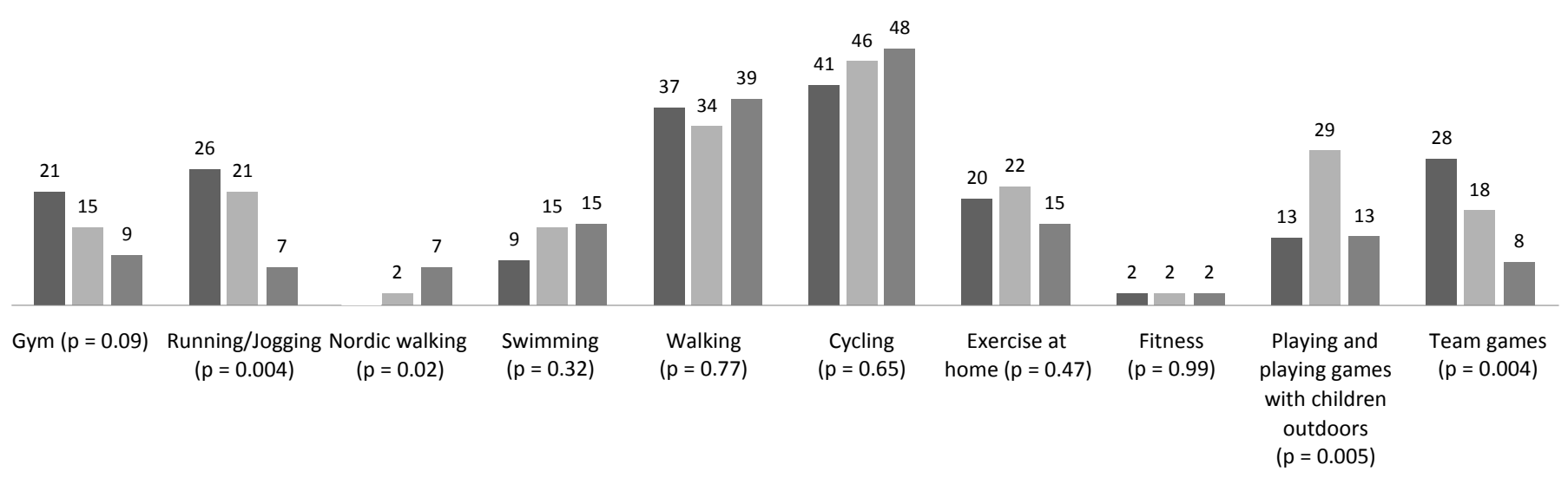

Figure 2. Popularity of selected forms of physical activity among male respondents in particular age groups [\%]

gender and age of the respondents. In their free time, women most often preferred walking and cycling. These two forms of activity also dominated among men, but in their case, cycling was the predominant activity. Many young women (22-34 years) engaged in running/jogging and fitness exercise. With age, however, women's interest in them gradually decreased $(\mathrm{p}=0.001$ and $\mathrm{p}=0.003$, respectively). Women aged 35-45 years were found to be the most active. This age group dominated amongst women who used the gym and swimming pool, walked, cycled, performed exercise at home, and spent their time with children in the open air in an active way. The women from the oldest age group (46-64 years) preferred Nordic walking more than the other age groups (fig. 1).

In the case of the male respondents, with age, the percentage of persons practising Nordic walking increased $(p=0.02)$, whereas the following forms of activity became less popular: exercising at the gym $(\mathrm{p}=0.09)$, running/jogging $(\mathrm{p}=0.004)$, and team games $(\mathrm{p}=0.004)$ (fig. 2$)$.

The respondents' motivation for spending their free time in an active way played a decisive role in selecting particular forms of physical activity. The desire to lose weight or maintain a healthy weight motivated the respondents to undertake several different forms of physical activity (tab. 1). It encouraged them to engage in the following: playing and playing games with children in the open air ( $\mathrm{OR}=2.48 ; \mathrm{CI}=1.61-3.80)$, doing gymnastic exercise at home ( $\mathrm{OR}=2.46 ; \mathrm{CI}=1.71-3.53)$, doing fitness exercise $(\mathrm{OR}=2.33 ; \mathrm{CI}=1.45-3.75)$, running $(\mathrm{OR}=2.32 ; \mathrm{CI}=$ $1.43-3.78)$, walking $(\mathrm{OR}=2.11 ; \mathrm{CI}=1.55-2.88)$, swimming (OR $=2.08 ; \mathrm{CI}=1.29-3.34)$, and playing team games $(\mathrm{OR}=1.86 ; \mathrm{CI}$ $=1.05-3.30$ ).

The respondents who cared for their health were likely to choose the following forms of motor activity: Nordic walking $(\mathrm{OR}=4.43 ; \mathrm{CI}=2.23-8.83)$, cycling $(\mathrm{OR}=3.41 ; \mathrm{CI}=2.50-4.65)$, walking $(\mathrm{OR}=2.56 ; \mathrm{CI}=1.86-3.53)$, swimming $(\mathrm{OR}=2.46 ; \mathrm{CI}=$ $1.50-4.02)$, doing gymnastic exercise at home $(\mathrm{OR}=2.30 ; \mathrm{CI}=$ $1.58-3.37)$, and, less frequently, exercising at the gym $(\mathrm{OR}=1.41$; $\mathrm{CI}=2.56-4.65)$.

The respondents most often sought the possibility of relieving tension and stress by: walking ( $\mathrm{OR}=2.68$; $\mathrm{CI}=1.96-3.66)$, doing fitness exercise $(\mathrm{OR}=2.58 ; \mathrm{CI}=1.61-4.14)$, running $(\mathrm{OR}=$ $2.14 ; \mathrm{CI}=1.31-3.49)$, cycling $(\mathrm{OR}=1.9 ; \mathrm{CI}=1.39-2.61)$, and doing gymnastic exercise at home $(\mathrm{OR}=1.74 ; \mathrm{CI}=1.22-2.50)$.
An interesting result was obtained in relation to the motivation stemming from the activity undertaken by one's friends. This motivation predisposed the respondents to undertake only one form of physical activity, that is swimming. The respondents who engaged in physical activity due to this motivating factor decided to practise swimming almost ten times more often than persons who did not have such support from their family and friends $(\mathrm{OR}=9.58 ; \mathrm{CI}=3.43-26.51)$.

Persons practising physical activity for pleasure most often chose team games or swimming (OR after 2.29) and they chose running $(\mathrm{OR}=1.96 ; \mathrm{CI}=1.21-3.18)$ and cycling $(\mathrm{OR}=1.69 ; \mathrm{CI}=$ 1.13-2.45) less frequently. However, those who wanted to change the shape of their body exercised at the gym $(\mathrm{OR}=2.50 ; \mathrm{CI}=$ 4.24-7.22), did running $(\mathrm{OR}=2.10$; $\mathrm{CI}=1.26-3.50)$, or did fitness exercise $(\mathrm{OR}=2.03 ; \mathrm{CI}=1.22-3.38)$ more often.

The motor activities which were found to be the most popular amongst administrative and office workers included: walking (44\% of all respondents surveyed), cycling (38\%), and doing gymnastic exercise at home $(22 \%)$. These three most popular forms of activity were most commonly undertaken for healthrelated purposes. The main predictors for practising walking were: the need to relieve tension and stress $(\mathrm{OR}=2.68 ; \mathrm{CI}=$ 1.96-3.66) and the desire to care for one's health $(\mathrm{OR}=2.56$; $\mathrm{CI}=1.86-3.53)$. The main motivation for cycling was the need to care for one's health $(\mathrm{OR}=3.41 ; \mathrm{CI}=2.50-4.65)$. Those who did gymnastic exercise at home were motivated not only by the need to care for their health $(\mathrm{OR}=2.30 ; \mathrm{CI}=1.58-3.37)$, but also largely by the desire to lose weight or maintain a healthy weight $(\mathrm{OR}=2.46 ; \mathrm{CI}=1.71-3.53)$.

The greatest probability of choosing a particular form of motor activity was recorded in relation to playing and playing games with children in the open air. Persons who wanted to strengthen family bonds chose such a form of resting in an active way over 26 times more often than persons who were not motivated by this desire in undertaking physical activity $(\mathrm{OR}=$ 26.47; CI = 14.88-47.08).

\section{Discussion}

The findings of the study presented in this article show that the choice of a particular motor activity depended on the type 
Table 1. Results of multivariate analyses of the logistic regression (odds ratio and 95\% confidence interval) showing the determinants of practising different forms of physical activity

\begin{tabular}{|c|c|c|c|c|c|c|c|c|c|c|c|c|}
\hline \multirow[b]{2}{*}{$\begin{array}{l}\text { Forms of physical } \\
\text { activity performed } \\
\text { regularly }\end{array}$} & \multicolumn{12}{|c|}{ Motivation for performing physical activity } \\
\hline & $\begin{array}{c}\text { Losing } \\
\text { weight or } \\
\text { maintaining } \\
\text { a healthy } \\
\text { weight }\end{array}$ & $\begin{array}{l}\text { Changing } \\
\text { the shape } \\
\text { of one's } \\
\text { body }\end{array}$ & $\begin{array}{l}\text { Caring } \\
\text { for one's } \\
\text { health }\end{array}$ & $\begin{array}{l}\text { Regener- } \\
\text { ating the } \\
\text { body }\end{array}$ & $\begin{array}{l}\text { Increasing } \\
\text { physical } \\
\text { fitness }\end{array}$ & $\begin{array}{l}\text { Relieving } \\
\text { tension } \\
\text { and stress }\end{array}$ & $\begin{array}{l}\text { Having a } \\
\text { friend who } \\
\text { performs } \\
\text { this } \\
\text { activity }\end{array}$ & $\begin{array}{l}\text { Having an } \\
\text { opportunity } \\
\text { to see one's } \\
\text { friends/meet } \\
\text { new people }\end{array}$ & $\begin{array}{l}\text { Strength- } \\
\text { ening } \\
\text { family } \\
\text { bonds }\end{array}$ & $\begin{array}{l}\text { Filling } \\
\text { one's free } \\
\text { time }\end{array}$ & $\begin{array}{l}\text { Deriving } \\
\text { pleasure } \\
\text { from } \\
\text { physical } \\
\text { activity }\end{array}$ & $\begin{array}{l}\text { Reducing } \\
\text { the risk of } \\
\text { diseases }\end{array}$ \\
\hline $\begin{array}{l}\text { Exercising at the } \\
\text { gym }\end{array}$ & & $\begin{array}{c}2.50 \\
(4.24-7.22)\end{array}$ & $\begin{array}{c}1.41 \\
(2.56-4.65)\end{array}$ & & $\begin{array}{c}1.76 \\
(3.02-5.16)\end{array}$ & & & & $\begin{array}{c}0.02 \\
(0.13-0.98)\end{array}$ & & & \\
\hline Running/Jogging & $\begin{array}{c}2.32 \\
(1.43-3.78)\end{array}$ & $\begin{array}{c}2.10 \\
(1.26-3.50)\end{array}$ & & & $\begin{array}{c}2.96 \\
(1.85-4.72)\end{array}$ & $\begin{array}{c}2.14 \\
(1.31-3.49)\end{array}$ & & & & & $\begin{array}{c}1.96 \\
(1.21-3.18)\end{array}$ & \\
\hline Nordic walking & & & $\begin{array}{c}4.43 \\
(2.23-8.83)\end{array}$ & & & & & & & & & \\
\hline Swimming & $\begin{array}{c}2.08 \\
(1.29-3.34)\end{array}$ & & $\begin{array}{c}2.46 \\
(1.50-4.02)\end{array}$ & & & & $\begin{array}{c}9.58 \\
(3.46- \\
26.51)\end{array}$ & & & & $\begin{array}{c}2.29 \\
(1.43-3.65)\end{array}$ & \\
\hline Walking & $\begin{array}{c}2.11 \\
(1.55-2.88)\end{array}$ & & $\begin{array}{c}2.56 \\
(1.86-3.53)\end{array}$ & $\begin{array}{c}1.85 \\
(1.26-2.71)\end{array}$ & & $\begin{array}{c}2.68 \\
(1.96-3.66)\end{array}$ & & & $\begin{array}{c}2.13 \\
(1.23-3.66)\end{array}$ & & & \\
\hline Cycling & & & $\begin{array}{c}3.41 \\
(2.50-4.65)\end{array}$ & & & $\begin{array}{c}1.91 \\
(1.39-2.61)\end{array}$ & & & $\begin{array}{c}2.18 \\
(1.30-3.66)\end{array}$ & $\begin{array}{c}2.21 \\
(1.34-3.64)\end{array}$ & $\begin{array}{c}1.67 \\
(1.13-2.45)\end{array}$ & \\
\hline $\begin{array}{l}\text { Doing gymnastic } \\
\text { exercise at home }\end{array}$ & $\begin{array}{c}2.46 \\
(1.71-3.53)\end{array}$ & & $\begin{array}{c}2.30 \\
(1.58-3.37)\end{array}$ & $\begin{array}{c}1.92 \\
(1.31-2.82)\end{array}$ & & $\begin{array}{c}1.74 \\
(1.22-2.50)\end{array}$ & & & & & & \\
\hline $\begin{array}{l}\text { Doing fitness } \\
\text { exercise }\end{array}$ & $\begin{array}{c}2.33 \\
(1.45-3.75)\end{array}$ & $\begin{array}{c}2.03 \\
(1.22-3.38)\end{array}$ & & & $\begin{array}{c}2.29 \\
(1.46-3.60)\end{array}$ & $\begin{array}{c}2.58 \\
(1.61-4.14)\end{array}$ & & & & & & \\
\hline $\begin{array}{c}\text { Playing and playing } \\
\text { games with children } \\
\text { in the open air }\end{array}$ & $\begin{array}{c}2.48 \\
(1.61-3.80)\end{array}$ & & & & & & & & $\begin{array}{c}26.47 \\
(14.88- \\
47.08) \\
\end{array}$ & & & $\begin{array}{c}1.91 \\
(1.11-3.29)\end{array}$ \\
\hline $\begin{array}{l}\text { Playing team games } \\
\text { (football, etc.) }\end{array}$ & $\begin{array}{c}1.86 \\
(1.05-3.30)\end{array}$ & & & & $\begin{array}{c}2.14 \\
(1.21-3.77)\end{array}$ & & & $\begin{array}{c}5.21 \\
(2.76-9.82)\end{array}$ & & & $\begin{array}{c}2.29 \\
(1.28-4.11)\end{array}$ & \\
\hline
\end{tabular}

of motivation which encouraged the respondents to spend their free time in an active way. This information may be of importance for those who are going to develop preventive programmes aimed to increase the level of the physical activity of Polish people. One such initiative on a national scale is the National Health Programme for the years 2016-2020, which is to reduce the percentage of Poles who are not physically active by $10 \%$ compared to the current figure [15].

The starting point for our study was to establish the determinants of physical activity amongst persons employed in administrative and office positions. We intended to focus on this group since persons belonging to it are at a high risk for having a sedentary lifestyle. In light of the law, employers are obliged to care for the health and lives of their employees, therefore the workplace holds great potential for promoting physical activity. Being aware of the motivation for choosing particular forms of physical activity, one can adapt the support employees receive from the employer to their needs and preferences and decide whether to subsidise passes to the gym, swimming pool, or fitness centres. The analysis conducted in this study can also be drawn upon by those who are working to educate Poles in order to influence the knowledge and attitudes of professionally active persons regarding the benefits of undertaking physical activity, so that they are willing to make a long-term commitment to taking care of their health.
It is difficult to change fixed patterns of behaviour which are followed in everyday life. Certain habits which many citizens of well-developed countries have, such as using the car and elevator or resting in a passive way, have caused a decrease in the percentage of active persons in those societies. One important source of motivation for undertaking physical activity can be family or friends. Our research has shown that almost ten times more respondents decided to engage in swimming if they had friends who regularly undertook such a form of physical activity. Having social support and friends who have healthy behavioural patterns makes it easier to overcome feelings of reluctance and a lack of motivation for changing one's lifestyle to a more active one. Królikowska's [16] research conducted amongst the residents of Opole aged 50+ who systematically did gymnastic exercise confirmed this hypothesis. The women who participated in the study admitted that they had decided to take part in gymnastics classes due to the fact that their friends attended such classes. This motivating factor significantly dominated over other factors, because it was mentioned in $70 \%$ of all responses. Another research study, this time conducted in the form of lectures with participants of classes held at fitness clubs and gyms, also pointed to the important role of the social factor in motivating people to have an active lifestyle. Face-toface conversations with the participants of the research made it possible to establish that such support is particularly important 
in the initial period of practising a given form of physical activity, when a given person is not familiar with the way a professional fitness centre operates. Social support makes it possible for them to adapt to a new environment and minimises the feeling of "being a stranger". The longer a person uses the services of fitness centres, the less important it is for them to have friends and family present with them [17].

In Poland, Nordic walking has become increasingly popular in the past few years. The research conducted by Siedlikowska [18] shows that although the dominant group of people interested in this type of activity are people aged 51-55 years, young people also enjoy this activity. The main factors predisposing people to engage in Nordic walking are the willingness to improve their physical fitness and general well-being (55\% of respondents) as well as the possibility to exercise in the open air and enjoy nature (53\%). In our research, the only significant predictor of engaging in Nordic walking was the need to care for one's health. It is worth mentioning that this form of activity is often recommended by doctors to patients from all age groups as a way of preventing disease [19].

With age, the risk that a person will cease to practise their preferred forms of physical activity on a level which meets the needs of the body increases. In a study by Jopkiewicz et al. [20], this tendency was observed both amongst women and men; however, women in all age groups engaged in different forms of physical activity less frequently. A similar trend was found in our research with respect to activities such as running/jogging and team games. However, it is not always the case that older women are the ones who undertake physical activity the least often. Nordic walking is the most popular form of activity amongst women, and especially those in the oldest age group. Based on in-depth interviews conducted at the request of the Polish Ministry of Sport and Tourism, it was concluded that women from older age groups choose lighter forms of activity, which are carried out irregularly depending on favourable weather conditions and the season of the year [21].

To sum up, based on the analyses of the findings of our research and that carried out by other authors, it can be stated that although the samples were not representative, valuable information was obtained concerning factors which motivate persons from the groups which were surveyed to undertake particular types of motor activity.

\section{Conclusions}

1. The regression model which was used included several important variables. This means that it helped clarify the mechanisms determining the choice of particular forms of physical activity in the group of administrative and office workers.

2. The predominant forms of physical activity which were regularly undertaken by the respondents were walking and cycling. The main predictor for engaging in walking was the need to relieve tension and stress, while the main motivating factor for practising cycling was the desire to care for one's health.

3. Having friends or family who engage in physical activity was found to motivate the respondents to swim regularly.

4. Another important motivating factor for physical activity was strengthening family bonds. This type of motivation led the respondents to engage in playing and playing games with children in the open air.

\section{Literature}

1. Griffiths K., Mackey M., Adamson B., Pepper K. (2012). Prevalence and risk factors for musculoskeletal symptoms with computer based work across occupations. Work 42(4), 533541. DOI: 10.3233/WOR-2012-1396.

2. Church T., Thomas D., Tudor-Locke C., Katzmarzyk P., Earnest C., Rodarte R. et al. (2011). Trends over 5 decades in US occupation-related physical activity and their associations with obesity. PloS One 6(5), el9657. DOI: 10.1371/journal. pone.0019657.

3. Uffelen J., Wong J., Chau J., Ploeg H., Riphagen I., Gilson N. et al. (2010). Occupational sitting and health risks: a systematic review. American Journal of Preventive Medicine 39(4), 379-88. DOI: 10.1016/j.amepre.2010.05.024.

4. Chodinow W. (2008). Role of active rest in circuit training. Collection of Research Papers from the Eastern European National University in Lutsk. Lutsk, 360-363. [in Polish]

5. Sygit K. (2015). Fundamental significance of physical activity for seniors' health. Central European Journal of Sport Sciences and Medicine 12(4), 53-59.

6. European Commission. (2014). Sport and physical activity. Special Eurobarometer 412. Brussels: European Commission. DOI: 10.2766/73002.

7. Kowalczyk A., Kozłowska E. (2015). Motives and limitations of physical activity in the professional group of office workers. Journal of Education, Health and Sport 5(9), 413-428.

8. Kozłowska E., Kowalczyk A., Rząca M., Kocka K. (2015). The impact of selected sociodemographic factors on motor activity of the office workers. Journal of Education, Health and Sport 5(6), 141-156.

9. Biernat E., Stupnicki R. (2005). Review of international questionnaires used in research into physical activity. Wychowanie Fizyczne i Sport 49, 32-42. [in Polish]

10. Kwasiborski P., Sobol M. (2011). Chi-square independence test and its application in the interpretation of clinical trial results. Kardiochirurgia i Torakochirurgia 4, 550-554. [in Polish]

11. Markowicz I., Stolarz B. (2009). Effect of encoding variables on the interpretation of the parameters of logistic regression models. Prace i Materiały Wydziału Zarządzania Uniwersytetu Gdańskiego 4(2), 621-630. [in Polish]

12. Public Opinion Research Center (CBOS). (2013). Communication on Research BS/129/2013. Physical activity of Poles. Warszawa: CBOS. [in Polish]

13. Olszewski-Strzyżowski J., Dróżdż R. (2014). Motivation for undertaking physical activity among residents of Elbląg. Rozprawy Naukowe Akademii Wychowania Fizycznego we Wrocławiu 47, 124-130. [in Polish]

14. Latosik E., Planeta K., Stachura A. (2011). Move, because... you will rust up - motives and obstacles for undertaking physical activity in librarians from Katowice. Bibliotheca Nostra 1(23), 18-19. [in Polish]

15. Polish Council of Ministers. (2015). Draft resolution of the Polish Council of Ministers on establishing the "National Health Programme for the years 2016-2020". Retrieved October 3, 2015 from http://legislacja.rcl.gov.pl/docs//2/ 12270850/12281779/12281780/dokument164277.pdf. [in Polish]

16. Królikowska B. (2014). Health benefits of gymnastics in persons aged 50 +. In A. Kostecka, H. Żukowska, M. SzarkEckardt, R. Muszkieta, E. Bendikova (eds), Education, physical activity, and health (pp. 147-158). Bydgoszcz: Polska: Oficyna Wydawnicza Mirosław Wrocławski. [in Polish] 
17. Bazuń D. (2013). Why bother? Motivating factors for performing physical activity in fitness clubs - research findings. Rocznik Lubuski 39(1), 197-211. [in Polish]

18. Siedlikowska M. (2012). Nordic walking in the opinion of participants of organised exercise. Zeszyty Naukowe Uniwersytetu Szczecińskiego 771, 187-196. [in Polish]

19. Kapoor S. (2013). Nordic walking and its clinical benefits in different disorders. Disability and Rehabilitation 35(19), 1676.
20. Jopkiewicz A., Gawron J. (2015). An assessment of the physical activity of adults residing in the Świętokrzyskie Region. Polish Journal Sport and Tourism 22, 84-93.

21. Polish Ministry of Sport and Tourism. (2015). Study of the motivation for undertaking physical activity in elderly people. Report on the implementation of the project. Warszawa: GfK Polonia Sp. z o.o. [in Polish]

Submitted: January 27, 2016

Accepted: March 21, 2016 